\title{
Research on Management and Control of Educational Cost in Higher Education
}

\author{
DU Guoliang ${ }^{1, a}$, XIA Jing ${ }^{2, b_{*}}$ \\ ${ }^{1}$ Finance Department, Wuhan University of Textile, \\ Wuhan, P.R. China, 430200 \\ ${ }^{2}$ Finance Department, Wuhan University of Textile, \\ Wuhan, P.R. China, 430200 \\ a e-mail: 95255286@qq.com, be-mail: callidora2015@163.com
}

Key words: Higher education, Cost calculation, Cost management, Cost control

\begin{abstract}
Because of the different referential foreign theories, the theory of educational cost calculation in Chinese higher education has not been unified yet. Besides, it is also obsessed by undecided calculating objects, non-profit orientation of the public colleges and universities, inadequate supervision and so on. Obviously, it is very urgent to strengthen the cost management in higher education. And the charging standard in colleges and universities should be reasonable and rational enough to guarantee its considerable development. Thus, based on the situation and necessity of educational cost calculation, the author here proposes four measures which are expected to afford the reform of calculating system references.
\end{abstract}

\section{Introduction}

To comply with the developments and requirements of higher education as well the reality of its further progress, the Ministry of Finance promulgates the new financial and accounting system, which covers the cost calculation and management. This system technically supports the standardization of financial accounting in colleges mainly by formulating some new specifications from the aspects of applicable scope, cost measurement method, financial report preparation, etc. Accordingly, college administrators should promptly respond to the consequent changes and implementing difficulties and then sort out their ideas.

\section{Literature Review of Educational Cost Calculation in Higher Education}

For education, its investment and output are temporally and spatially different and thus results in the differences and particularity of their evaluation and cost calculation. [1] Early as the term educational cost appears in the end of the 1950s, it has not reached to agreement on its calculation. Scholars at home and abroad have interpreted it from kinds of angles. And the earliest definition can date back to two famous economists John Vaizy and Theodore W. Schulte in the last century; one is from Britain and the other America. [2] In 1958, John Vaizy published the monograph The Cost of Education which takes the example of the change in British higher education from the early 20th century to 1950s to list the types of educational output. Later, in 1963, Theodore W. Schulte presented three types of educational cost in his book The Economic Value Education, in which the term opportunity cost had great effect on the world. Domestically, educationalists and economists took up their study on educational cost in accordance with the training features in our higher education since 1980s. [3] And Professor Yuan Liansheng from Beijing Normal University, one important figure among them, firstly put forward the term educational cost in his book Educational Cost Accounting. However, government and educational circle didn't attached importance to it until the fund shortage in colleges and universities resulting from the college expansion. In 1997, the Ministry of Finance promulgated The Finance Regulations in Colleges and The Accounting Regulations in Colleges. And in the 21st century, the scale of higher education was expanded a lot and the pattern of was improved a lot which both conduced to its new acknowledged features. [4] A typical example is the promulgation of the improved regulations -- The Accounting Regulations in 
Colleges in January 1, 2014. It is fairly innovative. On one hand, it requires colleges to save money, improve cash management efficiency and implement performance management. On the other hand, it further specifies the types of expenditure and generalizes the structure and direction o $\mathrm{f}$ expenditure. [5] However, though this new regulation is theoretically supported and innovatively introduces the educational cost in higher education to the government supervision and, it is fairly short in operability and guidance. Some particularly serious problems are as follows.

Firstly, the current theory of educational cost calculation is not unified resulting from the different referential theories. With respect to the system of educational cost calculation in higher education, its accounting objects, accounting standards, capital utilization as well as relevant accounting assumptions and account names have been in line with the budget accounting system. As a result, the particularity of educational management, the institutional regulations and the integrity of the accounting contents are left out. Besides, the different statistic methods also lead to the inaccuracy of cost calculating, which longitudinally and transversely blocks the comparative analysis of the cost index of different colleges and then even negatively affects related admissions policy and investment plan of training expense.

Secondly, the accounting objects in higher education have not yet been decided. Actually, product cost calculation is aimed to know the cost, account the profit and finally determine the ratio of input to output. The product of colleges we mention here means the production deriving from students' knowledge and skills as well as the service they offer to other educational objects. Compared to other products, they have commons as well as differences. The common feature is that they all have cost. And the difference, namely the individuality of educational products, is that the profit of their products is difficult to be quantified timely. Thus, to develop a socially acknowledged cost calculation system for higher education and eventually prepare cost calculation sheet are very urgent and necessary. However, how to clearly define and accurately calculate an educational product caused considerable controversy. [6] The bone of contention is exactly the objects of products. Some hold that it means the products produced by each student, but others argue that it means educational service. No one is willing to compromise with the other, hence, the settings of accounting subject, objects of cost collection and methods of cost calculation will accordingly differ with the other. What's worse, it will directly influence the methods of cost calculation and the output information and even further influence the accounting and distribution of college profit. Apart from the controversy on objects of product, there is also another controversy on the cost collection and objects of expenditure resulting from the peculiarity of educational cost calculation in higher education. A major controversial point is that whether the scientific research funds of teaching staff can be classified as teaching cost. If yes, then how can we quantify the cost? Besides, whether the wage and allowance of retirees can be included in the educational cost is another point.

Thirdly, the non-profit orientation of public colleges and universities results in the inadequate cost supervision. By far, the government has not enacted strict financial management system for colleges and national authorities have not admitted educational cost as one indicator in the performance evaluation of colleges. What's worse, there is even no management institution of educational cost directly under the leadership of national authorities. Educational cost has to be calculated together with administrative cost calculation. Thus, for the management departments in colleges, there is no cost pressure and performance motivation to supervise educational cost.

\section{Significance of Educational Cost Calculation}

The improvement of educational cost calculation is very important not only simply for students and colleges but also for the whole educational industry.

Firstly, when taking students into consideration, the charging standards in colleges should be reasonable and rational considering. [7] It is known to most people that the charging system in colleges is closely related to most people's distribution of money and the stable healthy development of colleges. In China, in order to protect most citizens the rights of education, the government should guarantee that there are enough public colleges and universities which stably charge students tuition fees. Apart from the stability of tuition fees, the charging standards should 
also embrace scientificity and rationality which exactly mean no arbitrary educational charges. The chapter 9 in the Education Act clearly stipulates that "citizens regardless of their nationality, race, gender, occupation, property, religious belief, etc., according to law enjoy equal educational opportunities”. But this equality doesn't equally mean free. It is well known that domestic higher education now is characterized by its part-commonweal. That means, it is not compulsory -students have to pay the tuition fees. Therefore, it is very urgent to draw up a set of rational charging standards and define the allocation system among individual, family and the government in accordance with the situation of China. However, unexpectedly, many colleges nowadays charge randomly and excessively. As a result, it largely increases the burden on students' families, especially the poor family. What's worse, few students are too poor to enter the college and eventually have to give up the chance to receive higher education. Thus, to accurately quantify the educational cost index can not only keep the state funds allocation information-based and establish rational cost compensation mechanism but also logically, efficiently and transparently improve the resource allocation which contributes to the evaluation of government's responsibility, the rationalization of resource consumption and eventually enhance the fair competition and further the development of higher education.

Secondly, it is important to guarantee the healthy development of higher education. Nowadays, the higher education is obsessed by a lot of problems. What comes firstly is the funds shortage. Over the years, colleges are mainly supported by the government funds and supplemented by students' tuition fees. However, in recent years, with the college expansion which to some extent, expand educational opportunities, the government funding and tuition fees can not support higher education any more. Consequently, the huge financing gap, the faculty deficiency and slow update of teaching facilities are increasingly serious. Another problem is left over by history. In the past, since managers in colleges have never been under the pressure of benefits, they have not developed the sense of efficient use of funds and conservation of educational resources. What's worse, the out-of-date approaches to accounting, simple financial report and distortion of accounting information largely decline the passion and confidence of investors or donors. To solve these problems, college should develop the sense of economic benefits over cost management. It is a good way to attract social funds, expand financing channels and greatly support the sustainable development of colleges. With more funds, college can introduce more high-quality talents and improve teaching environment without the restrictions of funds and maximize the social and economic benefits of higher education.

\section{Measures for Educational Cost Control}

However, educational cost calculation only is not enough. Thus, colleges shall also enhance their control of educational cost. There are mainly four measures as follows.

First method is instructing administrators and staff to deeply understand the new regulation and to be prepared for any eventualities. One will develop his sense of responsibility and crisis when he is ready all the time to face any eventualities. It is the same with colleges. Though they enjoy financial allocations, they still, to some extent, have to be responsible for their own profits and losses. The more their profit is, the more teaching equipment and talents will be introduced and the more passion the staff will have. The new accounting system innovatively introduces the accrual basis and provides the accounting information for performance evaluation which both emphasizes the importance of cost management. With the growing development of cost management, there will be another more scientific and perfect system of cost calculation in higher education in the future. Besides, colleges should be cautious enough to improve the cost management chain by setting Allowance for Doubtful Accounts so that they can faithfully calculate the educational cost as well as reflect the fact of delay payment of tuition.

Second point is classifying the cost and grasping its essence. Obviously, educational cost is characterized by its indirectness and increment which make it necessary for colleges to fully consider its diversity and then classify it scientifically. For instance, according to its nature and use, it can be divided into material cost and human cost; according to the subjects' educational level, it 
can be divided into direct cost and indirect cost; and according to the subjects, it can be divided into teaching cost, cost of students' living and opportunity cost. Accordingly, colleges should as early as possible establish the system of educational cost.

Third point is establishing reasonable cost control hierarchy system. That means, colleges should set its target cost in accordance with national goals and market demands and stress the cost control system in each stage -- pre-the matter, in-the matter and after-the matter. Besides, colleges are considered to establish normative internal cost control system. That means, all functional departments like school leaders, dean's office, admissions office and teaching office are the subjects of cost control and accordingly responsible for it. Hence, they should pay attention to the whole process of the use of cost.

Fourth point is Attaching importance to the management and implementation of financial budget. Financial budget is not only a good preparation in advance but also an indicator of the overall management level. The comprehensive budget can optimize the allocation of college resources and format the responsibility, right and beneficiary of colleges, sectors and individuals. As a result, a perfect internal control mechanism appears and provides full supervision in the whole process.

\section{Conclusions}

Though the system of educational cost calculation has been improved a lot over the years, there are still many obsessions like undecided calculating objects, non-profit orientation of the public colleges and universities, inadequate supervision and so on. The author stresses the significance of educational cost calculation and proposes four optional measures -- preparing any eventualities, classifying different kinds of cost, establishing cost control hierarchy and stressing financial budgeting -- for educational cost control. The author hopes that these analysis and optional measures might provide some ideas for other relevant studies.

\section{Acknowledgement}

In this paper, the research was sponsored by Foundation of Science and Technology Department of Hubei Province (Project No. 2016ADC078); Project of Humanities and Social Science of Hubei Province (Project No. 17Y057), Foundation of Hubei Educational Committee (Project No. 2016GB036).

\section{References}

[1] P.N. Bukh,H.T. Larsen,J. Mouritsen. Constructing intellectual capital statements[J]. Scandinavian Journal of Management . 2001 (1)

[2] Mitchell RK,Agle BR,Wood DJ.Toward a Theory of Stakeholder Identification and Salience: Defining the Principle of Who and What Really Counts. The Academy of Management Journal . 1997

[3] Sakellaris, P,and A Spilimbergo.Business Cycles and Investment in Human Capital: International Evidence on Higher Education. Carnegie Rochester Conference Series on Public Policy . 2000

[4] Verhoeven J.The Changing Relationship between Government andUniversities in Three European Countries. Tsinghua Journal ofEducation . 2005

[5] Beckei WE.Paying the Piper:Productivity,Incentives,and Financingin U.S.Higher Education. Economics of Education Review . 2006 
[6] James Joe,„Leavell W Hadley,Maniam Balasundram.Fi-nancial planning. Managerial Finance . 2002

[7] Braunstein,A.,McGrath,M.,Pescatrice,D.Measuring the impact of income and financial aid offers on college enrollment decisions. Research in Higher Education . 1999 